\title{
TỔNG QUAN MÔ HÌNH CÔNG TÁC XÃ HộI VỚI NGƯỜI CAO TUỔI Ở VIÊT NAM
}

\author{
Võ Thuấn ${ }^{\text {a*}}$, Phạm Văn Tư \\ ${ }^{a}$ Khoa Công tác Xã hội, Trường Đại học Đà Lạt, Lâm Đồng, Việt Nam \\ ${ }^{b}$ Khoa Công tác Xã hội, Truờng Đại học Su phạm Hà Nội, Hà Nội, Việt Nam \\ *Tác giả liên hệ: Email: thuanv@dlu.edu.vn \\ Lịch sử bài báo \\ Nhận ngày 07 tháng 11 năm 2017 \\ Chỉnh sửa ngày 08 tháng 01 năm 2018 | Chấp nhận đăng ngày 16 tháng 01 năm 2018
}

\section{Tóm tắt}

Bài viết này tập trung phân tích nhũng nội dung co bản nhất vấn đề của người cao tuổi: Các đặc điểm tâm - sinh lý nguoời cao tuổi và các chính sách và hoạt động hỗ trợ đối với người cao tuổi ở Việt Nam. Trên cơ sở mô tả các hình thức chăm sóc người cao tuổi cũng nhu các mô hình công tác xã hội với người cao tuổi ở Hoa Kỳ, bài viết này tham chiếu và tìm kiếm nhũng mô hình chăm sóc nguời cao tuổi ở Việt Nam trong tương lai.

Từ khóa: Công tác xã hội; Công tác xã hội với người cao tuổi; Mô hình công tác xã hội; Người cao tuổi.

Mã số định danh bài báo: http://tckh.dlu.edu.vn/index.php/tckhdhdl/article/view/359

Loại bài báo: Bài báo nghiên cứu gốc có bình duyệt

Bản quyền @ 2018 (Các) Tác giả.

Cấp phép: Bài báo này được cấp phép theo CC BY-NC-ND 4.0 


\title{
AN OVERVIEW OF MODELS OF SOCIAL WORK FOR THE ELDERLY IN VIET NAM
}

\author{
Vo Thuan ${ }^{a^{*}}$, Pham Van Tu \\ ${ }^{a}$ The Faculty of Social Work, Dalat University, Lamdong, Vietnam \\ ${ }^{b}$ The Faculty of Social Work, Hanoi National University of Education, Hanoi, Vietnam \\ *Corresponding author: Email: thuanv@dlu.edu.vn \\ Article history \\ Received: November $07^{\text {th }}, 2017$ \\ Received in revised form: January $08^{\text {th }}, 2018 \mid$ Accepted: January $16^{\text {th }}, 2018$
}

\begin{abstract}
This article focuses on analyzing the most basic issues of the elderly: Psychophysiological characteristics of elderly, supportive policies and activities for the elderly in Vietnam. This paper also describes the forms of taking care of the elderly as well as the models of social work for the elderly in the United States. This research also compares different models and finds out the best models for taking care of the elderly in Vietnam in the future.
\end{abstract}

Keywords: Elderly; Model of social work; Social work; Social work with elderly.

Article identifier: http://tckh.dlu.edu.vn/index.php/tckhdhdl/article/view/359

Article type: (peer-reviewed) Full-length research article

Copyright () 2018 The author(s).

Licensing: This article is licensed under a CC BY-NC-ND 4.0 


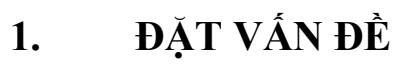

Công tác xã hội là một ngành khoa học, một nghề chuyên môn trong hệ thống an sinh xã hội của các quốc gia phát triển. Với tính cách là một ngành khoa học, công tác xã hội nghiên cứu con người trong mối tương tác với môi trường xã hội, nghiên cứu về các hệ thống xã hội nói chung cũng như các chính sách, dịch vụ xã hội, các nguồn lực hỗ trợ xã hội nhằm nâng cao quá trình trợ giúp cho con người. Đồng thời, công tác xã hội được xem là một ngành ứng dụng/thực hành.

Tính ứng dụng của công tác xã hội nằm ở chỗ chuyên môn của người có bằng công tác xã hội là một chuyên môn cụ thể, trực tiếp, có thể chuyển giao và lặp lại, và có tính chuyên sâu cao mà người ngoài ngành, nếu không được đào tạo, sẽ không thể tự có được. Cụ thể hơn, người có chuyên môn về công tác xã hội sẽ làm việc trực tiếp với các "thân chủ" theo nghĩa rộng (có thể là cá nhân, gia đình, cộng đồng) để lượng giá, chẩn đoán, lên kế hoạch, và giải quyết khó khăn cho thân chủ bằng các kỹ năng nghề trực tiếp (các ngành như xã hội học không có kỹ năng nghề tiêu biểu, mà chỉ có kiến thức) (Nguyễn \& Hines, 2011).

Công tác xã hội với người cao tuổi là một trong những lĩnh vực của công tác xã hội, theo đó nhân viên công tác xã hội sử dụng những kiến thức, phương pháp, kỹ năng, giá trị, đạo đức nghề nghiệp công tác xã hội đối với người cao tuổi dựa trên những nghiên cứu về các khía cạnh xã hội, tâm lý, văn hóa, sinh học và tinh thần của người cao tuổi.

Theo Luật Người cao tuổi Việt Nam 2009, người từ 60 tuổi trở lên, xét trên nhiều phương diện, với số lượng ngày càng tăng. Theo dự báo của Tổng cục Thống kê, tỷ lệ người cao tuổi sẽ chạm ngưỡng $10 \%$ tổng dân số vào năm 2017 , đó cũng là thời điểm Việt Nam bước vào giai đoạn "già hóa" dân số (Trịnh, 2016). Nhu cầu chăm sóc người cao tuổi ngày càng gia tăng, các số liệu nghiên cứu cho thấy cuộc sống người cao tuổi có sự thay đổi nhanh chóng. Người cao tuổi sống cùng con cái có xu hướng giảm rõ rệt, từ $79.73 \%$ năm 1993 xuống còn $57.22 \%$ năm 2010, trong khi người cao tuổi sống cô đơn và sống với vợ/chồng cao tuổi gia tăng nhanh chóng, lần lượt tăng từ $3.47 \%$ năm 1993 đến 6.81\% năm 2010, 9.48\% năm 1993 đến 24.84 năm 2010\% (Giang, 2013). Người cao tuổi là một trong nhóm xã hội yếu thế, dễ bị tổn thương, có nhiều nguy cơ rủi ro trong cuộc sống, với các vấn đề về thể chất, sức khỏe, thu nhập và mức độ ảnh hưởng xã hội. Hơn nữa, ở Việt Nam, qua hơn 30 năm đổi mới với quá trình phát triển kinh tế xã hội đã chứng kiến sự biến đồi các cấu trúc xã hội, cộng đồng và gia đình - nơi vốn là "tổ ấm", là điểm tựa vững chắc cho các thành viên trong gia đình, đặc biệt là người cao tuổi đã có sự suy yếu nghiêm trọng. Do đó, người cao tuổi càng dễ bị tổn thương, càng có nhiều vấn đề cần hỗ trợ, chăm sóc, quan tâm trong công tác xã hội. Bài viết này tập trung phân tích những nội dung cơ bản nhất vấn đề của người cao tuổi: Các đặc điểm tâm - sinh lý người cao tuổi và Các chính sách và hoạt động hỗ trợ đối với người cao tuổi ở Việt Nam; Mô tả các hình thức chăm sóc người cao tuổi cũng như các mô hình công tác xã hội với người cao tuổi ở Hoa Kỳ. Qua đó để có sự tham chiếu và tìm kiếm những mô hình chăm sóc người cao tuổi ở Việt Nam trong tương lai. Phương pháp 
nghiên cứu trong bài viết chủ yếu được kết hợp từ việc phân tích tài liệu thứ cấp với trao đổi ý kiến của chuyên gia trong lĩnh vực công tác xã hội.

\section{MỘT SỐ ĐẶC ĐIỄM TÂM SINH LÝ CỦA NGƯỜI CAO TUỔI}

\section{1. Đặc điểm sinh lý}

Đến giai đoạn người cao tuổi, đặc điểm cơ thể có những thay đổi theo chiều hướng đi xuống, hiện tượng lão hóa xuất hiện, các bộ phận trong cơ thể có những suy giảm về chức năng: Cường độ trao đổi chất giảm, hệ hô hấp, hệ tuần hoàn, hệ tiêu hoá, hệ bài tiết, khả năng tình dục... đều giảm sút và trì trệ. Độ nhạy cảm của các cơ quan cảm giác kém (mắt mờ, tai lãng...), tóc bạc, răng rụng, da nhăn nheo... Người cao tuổi cũng xuất hiện nhiều bệnh tật khác nhau như bệnh huyết áp cao, tai biến mạch máu não, đau đầu, giảm thị lực, loãng xương... và một số bệnh liên quan đến hệ thần kinh như Parkinson, Alzheimer.

\section{2. Đặc điểm tâm lý}

Khi bước sang giai đoạn này, người cao tuổi có những thay đổi tâm lý, dù khác nhau ở từng cá nhân, nhưng tựu trung có những thay đổi thường gặp là: Tính ham hiểu biết vẫn còn, hoạt động tư duy để ra quyết định chậm, nhưng do có nhiều kinh nghiệm, sự trải nghiệm nên quyết định của họ chín chắn. Trí nhớ ngắn hạn kém, nhưng trí nhớ dài hạn còn tốt nên họ thường quên những gì vừa xảy ra nhưng nhớ rất lâu những gì thuộc về quá khứ. Do những ảnh hưởng về mặt xã hội thu hẹp, người cao tuổi dễ gặp phải "hội chứng về hưu". Những biểu hiện tâm lý người cao tuồi có thể liệt kê như sau: Hướng về quá khứ; Sự cô đơn và mong được quan tâm, chăm sóc nhiều hơn; Cảm thấy bất lực và tủi thân; Nói nhiều hoặc trầm cảm; Sợ phải đối mặt với cái chết; và Tâm lý nghỉ hưu (Nguyễn \& Nguyễn, 2015). Với những thay đổi về tẩm lý như trên nên một bộ phận người cao tuổi sẽ thay đổi tính cách.

Người làm công tác xã hội trong lĩnh vực này cần có sự hiểu biết thực tế đặc điểm tâm lý người cao tuổi để có những ứng xử phù hợp. Tuy nhiên chúng ta cũng cần nhận thấy rằng có những đặc điểm tâm lý tích cực của người cao tuổi mà người làm công tác xã hội có thể tận dụng trong quá trình thực thi nghề nghiệp của mình một cách có hiệu quả, ví dụ như người cao tuồi có nhu cầu chia sẻ kiến thức, kinh nghiệm cho các thế hệ trẻ, con cái, có thời gian chăm sóc giáo dục con cháu trong gia đình. Người cao tuổi có nhiều trải nghiệm trong cuộc sống nên có cái nhìn bao dung, độ lượng trong cuộc sống... Những yếu tố tích cực này là những điểm mạnh của người cao tuổi mà nhân viên công tác xã hội cần hết sức lưu ý để có thể phát huy vai trò tốt đẹp của họ.

\subsection{Một số vấn đề khác của người cao tuổi}

Nhân viên công tác xã hội hay một người chăm sóc, chúng ta có thể trải nghiệm với người cao tuổi về một số vẩn đề khác như: Suy nghĩ về quá khứ, sự mất mát, đau buồn và đương đầu với cái chết. Họ thường có những sự đau buồn khác nhau về những trải nghiệm trong quá khứ, mối quan hệ với người đã mất (đặc biệt là khi vợ/chồng qua 
đời), những tình huống quanh cái chết, những ảnh hưởng đối với hiện tại, niềm tin vào ý nghĩa của cuộc sống... Vì thế, nhân viên công tác xã hội hay người chăm sóc cần hiểu rằng khi tiếp xúc với người cao tuổi bị bệnh hoặc đang hấp hối đòi hỏi một sự tận tâm và tự nguyện. Sẽ rất khó khăn để chứng kiến nỗi đau của người khác khi mà bạn không hiểu và thông cảm cũng như làm dịu đi sự đau đớn về tinh thần và thể xác của họ.

\section{CÁC CHÍNH SÁCH VÀ HOẠT ĐộNG HỖ TRỢ NGƯờI CAO TUỔI Ở VIẸT NAM}

Ở Việt Nam, chính sách và hoạt động chăm sóc người cao tuổi là nghĩa vụ, trách nhiệm của gia đình, cộng đồng và nhà nước, là truyền thống tốt đẹp của dân tộc ta từ ngàn xưa. Đạo lý "kính lão đắc thọ" "kính già, già để tuổi cho" là những giá trị tốt đẹp trong quan hệ, ứng xử với người cao tuổi. Sau khi Hội Người cao tuổi Việt Nam được thành lập (15/10/1995), Ban Bí thư Trung ương Đảng ra Chỉ thị 59/CT-TW về chăm sóc người cao tuổi, trong đó quy định về việc chăm sóc đời sống vật chất và tinh thần của người cao tuổi là trách nhiệm của Đảng, Nhà nước và toàn xã hội. Hội Người cao tuổi Việt Nam mới thành lập cần được nhanh chóng ổn định về tổ chức và mở rộng hoạt động ở cơ sở. Đảng đoàn Mặt trận Tổ quốc và các ban đảng, các đoàn thể nhân dân cần giúp đỡ Hội hoạt động có hiệu quả thiết thực, phối hợp với Hội trong việc vận động gia đình và xã hội chăm sóc, bồi dưỡng, phát huy người cao tuổi phục vụ công cuộc đổi mới. Đảng đoàn Quốc hội, Đảng đoàn Mặt trận tổ quốc Việt Nam, các ban của đảng, các ban cán sự đảng Chính phủ, Bộ Lao động, Thương binh và Xã hội, Bộ Y tế, Bộ Tư pháp phối hợp với Hội nghiên cứu, soát xét các chính sách luật pháp hiện hành, đề xuất những văn bản pháp quy của nhà nước nhằm bảo vệ, chăm sóc và phát huy người cao tuổi (VUSTA, 2007). Liên tục từ đó cho đến nay, Đảng, Nhà nước đã không ngừng ban hành những chính sách, luật pháp ngày càng hoàn thiện hơn trong việc chăm sóc, hỗ trợ người cao tuổi như những chính sách trợ cấp lương hưu, trợ cấp xã hội, trợ cấp bảo hiểm y tế. Năm 2009, Quốc hội thông qua Luật Người cao tuổi. Tiếp đó Chính phủ đã có Nghị định 06/2011 quy định chi tiết và hướng dẫn thi hành một số điều của Luật Người cao tuổi và một số nghị định khác. Các hoạt động thuộc chương trình hành động quốc gia về người cao tuổi giai đoạn 2011-2020 đã được triển khai, với chín hoạt động chủ yếu: Hoạt động phát huy vai trò người cao tuổi; Hoạt động chăm sóc sức khỏe; Hoạt động chăm sóc đời sống văn hóa tinh thần; Hoạt động tuyên truyền, giáo dục nâng cao nhận thức về các vấn đề liên quan đến người cao tuổi; Hoạt động nâng cao đời sống vật chất; Hoạt động xây dựng và nhân rộng mô hình chăm sóc và phát huy vai trò người cao tuổi dựa vào cộng đồng; Hoạt động phát triển các cơ sở chăm sóc và nhà ở đối với người cao tuổi; Hoạt động đào tạo, nâng cao năng lực cán bộ, giám sát, đánh giá nghiên cứu về những vấn đề liên quan người cao tuổi; và Hoạt động chủ động chuẩn bị cho tuổi già (Văn phòng Chính phủ, 2012).

Ngoài Luật Người cao tuổi, nhiều Bộ (Bộ Lao động, Thương binh và Xã hội, Bộ Tài chính, Bộ Nội vụ, Bộ Giao thông Vận tải, Bộ Văn hóa, Thể thao và Du lịch...) và các bộ luật chuyên ngành khác (Luật Hôn nhân gia đình, Luật Dân sự, Luật Lao động...) cũng ban hành những điều khoản dành riêng cho người cao tuổi. 
Theo Luật Người cao tuổi, các chính sách đối với người cao tuổi bao gồm hai lĩnh vực chính là: Phụng dưỡng, chăm sóc người cao tuổi và Phát huy vai trò của người cao tuổi trong cuộc sống. Lĩnh vực "chăm sóc", về lý thuyết có nội dung khá rộng, gồm: Bảo trợ xã hội (đảm bảo nhu cầu vật chất tối thiểu cho nhóm đối tương người cao tuổi yếu thể nhất, bảo đảm mức sống tối thiểu, nhà ở cho người cao tuổi cô đơn, nhà dưỡng lão); Chăm sóc sức khỏe (ưu tiên khám bệnh, cấp thẻ bảo hiểm y tế, hoạt động của các câu lạc bộ sức khỏe người cao tuổi) chăm sóc đời sống văn hóa tinh thần, tâm lý tình cảm (như chúc thọ, mừng thọ, mai táng, sinh hoạt tại các câu lạc bộ, chăm sóc người cao tuổi dựa vào cộng đồng) các dịch vụ đời sống (những chính sách ưu đãi người cao tuổi trong sử dụng dịch vụ công cộng như giao thông, tham quan, nghỉ dưỡng) (Trịnh, 2016).

Mặc dù các chính sách chăm sóc người cao tuổi ở Việt Nam hiện nay đã thể hiện được: Tính hệ thống và đầy đủ của các chính sách; Tính hợp lý trong việc phân chia theo đối tượng người cao tuổi; Tính khả thi của các chính sách; và Chính sách trợ giúp xã hội và các quyền của người cao tuổi (Trịnh, 2016). Tuy nhiên những chính sách và hoạt động trên chỉ đáp ứng một phần nhu cầu của người cao tuổi, số đông vẫn chưa tiếp cận được các dịch vụ chăm sóc y tế, chăm sóc sức khỏe công lập vẫn chưa đảm bảo nhu cầu khám chữa bệnh của người cao tuổi, nhất là người cao tuổi ở nông thôn, miền núi, vùng sâu, vùng xa.

Lĩnh vực chăm sóc người cao tuổi trong các văn bản chưa bao quát hết các chủ thể quan trọng cũng như chưa cân đối các vai trò chăm sóc. Vai trò của Nhà nước được đề cập chủ yếu trong các chính sách và được nhấn mạnh trong mô hình an sinh xã hội. Hai chủ thể gia đình và cộng đồng khá quan trọng trong chăm sóc người cao tuổi chỉ được nhắc đển dưới hình thức "động viên", nhắc nhở trách nhiệm đạo đức, chưa được thể chế hóa thành các quy định rõ ràng nên khó kiểm tra và giám sát kết quả thực hiện. Do đó phần nào tạo nên những khó khăn trong phối hợp giữa các chủ thể và hạn chế hoạt động công tác xã hội trong chăm sóc người cao tuổi (Bùi, 2015).

\section{MÔ HÌNH CHĂM SÓC NGƯờI CAO TUỔI Ở HOA KỲ}

Chuyên gia Trần (2017), người có gần 30 năm làm việc trong nhiều lĩnh vực của công tác xã hội ở Hoa Kỳ như trẻ em, người cao tuổi, sức khỏe tâm thần, và là người tích cực tham gia xây dựng nền giáo dục công tác xã hội Việt Nam, cho biết:

Hệ thống chăm sóc người cao tuổi ở Hoa Kỳ cũng là một mô hình kết hợp nhà nước, xã hội, gia đình như ở Việt Nam. Tuy nhiên đóng góp của mỗi thành phần có khác nhau. Ở Hoa Kỳ, xã hội giữ vai trò chủ yếu, nhất là đối với người cao tuổi nghèo. Luật pháp bắt buộc chính phủ phải cung cấp rất nhiều dịch vụ để bảo đảm an sinh tối thiểu cho người cao tuổi.

Việc chăm sóc người cao tuổi (65 tuổi trở lên) nghèo (không có thu nhập hoặc thu nhập dưới mức qui định) ở Hoa Kỳ có thể mô tả vắn tắt như sau (từ sức khỏe tốt đển sức khỏe yếu): 
Được bảo hiểm sức khỏe miễn phí của chính phủ liên bang, gọi là chương trình MediCare cộng với bảo hiểm sức khỏe miễn phí của tiểu bang nơi họ sinh sống, gọi là chương trình MediCaid. Riêng tại bang California, chương trình MediCaid được gọi là MediCal.

Người cao tuổi còn khỏe mạnh, sống tự lập được trợ cấp tiền mặt (tiền này trích từ quỹ thuế của chính quyền liên bang và của hạt, nên số tiền thay đổi tùy theo hạt giàu hay hạt nghèo). Ở những hạt giàu của bang California, số trợ cấp tiền mặt này là trên 800 USD/tháng, đủ cho người cao tuổi có thể sống tự lập ở mức tối thiểu mà không cần sự trợ giúp của con cái. Ngoài ra, tùy theo ngân quỹ của từng hạt, các chính quyền địa phương còn có chương trình trợ cấp nhà ở giá rẻ hoặc miễn phí cho người cao tuồi. Tuy nhiên, những chương trình này thường có danh sách chờ khá dài, có thể mất nhiều năm mới đến lượt.

Người cao tuổi có khả năng tiếp tục sống tại nhà nhưng cần trợ giúp: Chính quyền các hạt có chương trình "Trợ giúp tại nhà" (In-Home Supportive Service): Chương trình này trả tiền cho bất cứ ai, trên 18 tuổi, không có tiền án, bằng lòng cung cấp dịch vụ chăm sóc để người cao tuổi có thể tiếp tục sống tự lập tại nhà của họ. Những người chăm sóc này có thể là con, cháu, hàng xóm, bạn, hay họ hàng, hoặc người chuyên sống bằng nghề chăm sóc người cao tuổi. Hiện nay số tiền này tại Hạt Santa Clara, bang California, là hơn 13 USD/giờ. Số giờ sẽ do một nhân viên công tác xã hội của Sở "Trợ giúp tại nhà" làm lượng định trực tiếp với người cao tuổi, tùy theo nhu cầu và tình hình sức khỏe của người cao tuổi, thí dụ có thể tự tắm rửa được hay không, có thể tự đi chợ nấu ăn được hay không... số giờ có thể từ tối thiểu vài giờ/tháng, đến tối đa hơn 2000 giờ/tháng. Người chăm sóc có thể là con, cháu của người cao tuồi vì tại Hoa Kỳ cha mẹ bị bắt buộc phải nuôi dưỡng con dưới 18 tuổi nhưng con cháu không có trách nhiệm phải nuôi hay phụng dưỡng cha mẹ/ông bà.

Người cao tuổi không còn khả năng sống tại nhà và được bác sĩ giới thiệu, sẽ được đưa vào sống trong các nhà chăm sóc tập trung (nursing home) cho đến khi qua đời. Người cao tuổi không thuộc diện nghèo sẽ phải bỏ tiền túi ra để hưởng tất cả các dịch vụ chăm sóc. Đây là thị trường rất lớn của mảng công tác xã hội tư. Không có sự phân biệt giữa người cao tuổi làm cho nhà nước hay tư nhân.

Ở Hoa Kỳ không có luật ấn định tuổi về hưu như Việt Nam. Chính phủ liên bang có luật qui định người cao tuồi (không phân biệt nam nữ như Việt Nam) có đi làm và đóng tiền vào quỹ hưu bổng liên bang SS (Social Security) thì từ 62 tuổi có quyền làm thủ tục với cơ quan quản lý quỹ SS để bắt đầu rút tiền ra hàng tháng (cho đến khi qua đời). Tuy nhiên, người cao tuổi có quyền chọn tuổi về hưu cho bản thân. Nếu bắt đầu nghỉ hưu (rút tiền SS) từ 62 tuổi thì chỉ được lĩnh $75 \%$ số tiền đáng lẽ được hưởng. Tuổi được hưởng $100 \%$ tiền hưu là 65 đối với những người sinh từ 1937 trở về trước. Đối với những người sinh sau 1937 thì mỗi năm sinh sau phải cộng thêm 2 tháng mới đủ tuổi để lĩnh 100\% tiền hưu. Thí dụ đối với người sinh năm 1938, tuổi về hưu (được lĩnh 100\% số tiền hưu của mình) là 65 tuổi 2 tháng... Đối với người cao tuổi đang về hưu hiện nay (sinh trong khoảng từ 1943-1954, tuổi được lĩnh 100\% tiền hưu của mình là 66). Sau khi đã quyết định lĩnh tiền hưu của chính phủ liên bang, người về hưu chỉ được phép đi 
làm thêm ở mức lương $15.720 \mathrm{USD} /$ năm, nếu làm trên mức lương này thì cứ kiếm thêm được 2 USD trên mức qui định (15.720 USD), tiền hưu (SS) sẽ bị giảm 1 USD.

Ngoài tiền hưu kể trên do đã đóng góp vào quỹ SS (gần như tất cả mọi người đi làm ở Mỹ, bất kể lĩnh vực công hay tư, đều phải đóng góp hàng tháng vào quỹ SS của chính phủ liên bang), người cao tuổi còn có thể được hưởng chể độ hưu của cơ quan/tổ chức, nơi họ làm việc. Số tiền hưu này nhiều ít tùy theo cơ quan/tổ chức và tùy theo thời gian làm việc. Nhiều cơ quan/tổ chức tư nhân không có chế độ hưu này. Ngoài ra, Hoa Kỳ còn có luật cho phép người đi làm hàng tháng đóng tiền (nhiều ít tùy ý) vào quỹ về hưu riêng, số tiền này không bị tính vào thu nhập hàng tháng, nhờ vậy giảm được thuế thu nhập. Khi về hưu sẽ rút số tiền này ra và chịu thuế thu nhập (ít hơn thời gian đi làm vì tiền hưu không nhiều bằng tiền lương). Ở Hoa Kỳ có nhiều hội người cao tuổi nhưng là tất cả đều là hội tư nhân, hoạt động giống như tất cả các hội tư nhân khác. Chẳng hạn AARP (American Association for Retired Persons) thành lập từ 1958 là hội lớn nhất, có chi nhánh trên toàn quốc.

Ngoài ra có sự liên tục của dịch vụ người cao tuổi tại Hoa Kỳ như: Các trung tâm chăm sóc người cao tuổi vào ban ngày; Dịch vụ bảo vệ người cao tuổi bị bạo hành; Dịch vụ quản lý chăm sóc; Giáo dục người chăm sóc, tham vấn, nhóm hỗ trợ; Chương trình dịch vụ hỗ trợ tại nhà; Nhà tế bần; Bệnh viện; Trung tâm quản lý chăm sóc lão khoa tư nhân; Trung tâm cao cấp; Dịch vụ di chuyển; Dịch vụ cựu binh; và Chương trình dinh dưỡng "bữa ăn trên bánh xe" (chương trình giao bữa ăn nấu sẵn miễn phí hoặc giá rẻ đến tận nhà người cao tuổi không có người chăm sóc).

Trong thế kỷ XXI, chương trình người cao tuổi vẫn đang tiếp tục tập trung vào sự chăm sóc dựa vào cộng đồng, nâng cao sức khỏe và thay đổi chương trình y tế. Chính phủ khuyến khích người cao tuổi mua bảo hiểm cá nhân chăm sóc dài hạn và bảo hiểm bổ sung để trang trải những thiếu hụt trong chăm sóc.

\section{MÔ HİNH CÔNG TÁC XÃ HộI VỚI NGƯời CAO TUỔI Ở VIẸT NAM}

Tại Việt Nam, các cơ sở chăm sóc người cao tuổi theo Luật Người cao tuổi năm 2009 bao gồm: Cơ sở bảo trợ xã hội; Cơ sở tư vấn, dịch vụ chăm sóc người cao tuổi; và Cơ sở chăm sóc người cao tuổi khác. Vai trò của của công tác xã hội thể hiện ở hai hình thức: Chăm sóc người già cô đơn trong các cơ sở bảo trợ xã hội; và Cung ứng dịch vụ chăm sóc người cao tuổi tại gia đình và cộng đồng. Có các mô hình chăm sóc người cao tuổi liên quan đến bốn chủ thể gồm nhà nước, gia đình, cộng đồng và thị trường như sau: (i) Trung tâm bảo trợ xã hội là mô hình do Nhà nước trợ cấp hoàn toàn; (ii) Mô hình nhà dưỡng lão tư nhân - mang tính thị trường; và (iii) Mô hình chăm sóc người cao tuổi tại cộng đồng bởi người thân trong gia đình, họ hàng, làng xóm (Bùi, 2015).

Mỗi mô hình có những đặc thù, tính chất, hiệu quả khác nhau, đáp ứng các nhu cầu và hoàn cảnh của người cao tuổi. Hoạt động của nhân viên công tác xã hội trong các trung tâm bảo trợ xã hội là tiếp nhận đối tượng, thăm hỏi động viên; Hướng dẫn, chăm sóc người cao tuổi thực hiện các hoạt động cá nhân, chăm sóc sức khỏe; Tổ chức các hoạt động văn hóa, thể thao; Giúp người cao tuổi thường xuyên duy trì mối liên hệ với 
gia đình, người thân; và Hỗ trợ tham vấn tâm lý, ghi chép và quản lý hồ sơ. Trung tâm bảo trợ xã hội có độ bao phủ rộng khắp toàn quốc, đã giúp phần lớn người cao tuổi không nơi nương tựa được chăm sóc, nuôi dưỡng. Tuy nhiên, cơ sở vật chất của các trung tâm này nhìn chung còn nhiều hạn chế, thiếu thốn, nguồn nhân lực có chuyên môn chưa đáp ứng yêu cầu, chỉ được đáp ứng nhu cầu này ở mức tối thiểu, chủ yếu vẫn là chăm sóc, nuôi dưỡng và chăm sóc y tế cho người cao tuổi là chính.

Do tính chất kinh tế, văn hóa và lịch sử đặc thù nên các hoạt động công tác xã hội với người cao tuổi ở Việt Nam có những nét đặc thù, người cao tuổi được gia đình, Nhà nước và xã hội chăm lo, phụng dưỡng. Hình thức cung ứng dịch vụ chăm sóc người cao tuổi tại gia đình và cộng đồng thường là cơ sở xã hội tiếp nhận cử nhân viên công tác xã hội đển gia đình họ trực tiếp thực hiện các dịch vụ tư vấn, đánh giá, xác định vấn đề, giúp xây dựng kế hoạch, thiết lập các mối quan hệ trong gia đình và xã hội, cung cấp các dịch vụ công tác xã hội, tạo môi trường hỗ trợ tốt nhất cho người cao tuổi (Bùi, 2015).

Quá trình phát triển kinh tế xã hội đã phá vỡ cấu trúc gia đình (từ gia đình mở rộng chiếm ưu thế sang gia đình hạt nhân là chủ đạo). Hiện nay, loại hình gia đình cha mẹ không cùng con cái ở chung đã gia tăng. Do vậy, nhu cầu chăm sóc người cao tuổi là một đòi hỏi tất yếu và rất cần thiết. Hơn nữa, bản thân người cao tuổi có tiền, hoặc con cái họ thành đạt nhưng không có thời gian chăm sóc nên gửi người cao tuổi đến các trung tâm chăm sóc người cao tuổi như Trung tâm Chăm sóc người già Thiên Đức, Trung tâm Chăm sóc người cao tuổi Nhân Ái ở Hà Nội, và một số trung tâm chăm sóc người cao tuổi ở Đà Nẵng, Thành phố Hồ Chí Minh. Các trung tâm này hoạt động giống như mô hình nhà dưỡng lão ở các nước phát triển, cung cấp dịch vụ lợi nhuận, nuôi dưỡng người cao tuổi bằng nguồn đóng góp của gia đình họ. Người cao tuổi ở các trung tâm thường được chia thành hai nhóm: Nhóm những người cao tuổi bị bệnh nặng không thể đi lại được chăm sóc về dinh dưỡng và y tế bởi các bác sĩ và các điều dưỡng viên nhằm phục hồi sức khỏe cho người cao tuổi bằng các liệu pháp y học tương tự như tại các bệnh viện; Nhóm thứ hai là những người cao tuổi còn sức khỏe, có thể đi lại thì ngoài việc được chăm sóc về dinh dưỡng, $\mathrm{y}$ tế, họ còn được thụ hưởng dịch vụ tư vấn, tham vấn, quản lý trường hợp tương đối chuyên nghiệp bởi các nhân viên y tế, nhân viên công tác xã hội. Họ còn tham gia các hoạt động giải trí như xem ti vi, sinh hoạt tập thể, và tham gia các câu lạc bộ theo sở thích, yêu cầu. Cuối tuần, hoặc mỗi tháng 1-2 lần con cháu và người thân trong gia đình vào thăm họ và có thể ở lại cùng họ để trò chuyện, hoặc được con cháu đón về gia đình vào ngày nghỉ. Đây là mô hình nhìn chung đáp ứng tương đối tốt nhu cầu của người cao tuổi và gia đình. Tuy nhiên, loại hình chăm sóc này chưa phổ biến và chi phí còn rất cao so với thu nhập của đại đa số người cao tuổi.

Mô hình Trung tâm Trợ giúp người cao tuổi và Phát triển cộng đồng (CASCD) thuộc Trung ương Hội Chữ thập đỏ Việt Nam có các hoạt động liên quan đến dịch vụ công tác xã hội. Điển hình là việc xây dựng hàng loạt mô hình chăm sóc người cao tuổi tại nhà và cộng đồng, hơn 200 câu lạc bộ người cao tuổi và mạng lưới tình nguyên viên chăm sóc người cao tuổi. Tới năm 2015, CASCD có đội ngũ hơn 3.000 tình nguyện viên tại 15 tỉnh/thành (Bùi, 2015). Mục tiêu của các mô hình này nhằm trợ giúp trực tiếp 
những người cao tuổi ở gia đình và cộng đồng. Mô hình này ngoài việc chăm sóc người cao tuổi dựa vào con cháu, người thân trong gia đình, còn có sự hỗ trợ của các cá nhân khác trong cộng đồng, các tình nguyện viên phổ biến những kiến thức cần thiết về chăm sóc sức khỏe cho người cao tuổi, vận động, tìm kiếm những nguồn trợ giúp cho người cao tuổi có hoàn cảnh khó khăn. Hơn nữa, tình nguyện viên kịp thời phát hiện những nhu cầu cụ thể của người cao tuổi, làm cầu nối với chính quyền nắm bắt được nhu cầu và có giải pháp cho các vấn đề đặt ra cho người cao tuổi. Các hoạt động của mô hình này chưa hiệu quả khi cam kết của địa phương và phối kết hợp của các cơ quan chức năng và tổ chức đoàn thể còn chưa cao, kinh phí hạn hẹp và không được phân bổ qua ngân sách nên các hoạt động còn hạn chế, đặc biệt nâng cao kỹ năng cho nhóm thực hiện chăm sóc (Giang, 2013).

Phần lớn người cao tuổi ở Việt Nam hiện nay sống cùng con cái trong các gia đình, vẫn tiếp tục lao động khi tuổi đã cao và việc chăm sóc, phụng dưỡng người cao tuổi vốn là truyền thống văn hóa tốt đẹp của dân tộc Việt Nam. Tỷ lệ người cao tuổi năm 2012 là $10.2 \%$, năm 2013 là $10.3 \%$, năm 2014 là $10.5 \%$ và sẽ tăng gấp đôi lên $23 \%$ vào năm 2040 (Bùi, 2015). Đời sống gia đình, đời sống tinh thần và văn hóa của người cao tuổi thay đổi nhanh chóng. Mô hình và nguyên nhân bệnh tật của người cao tuổi đang thay đổi nhanh chóng, từ bệnh lây nhiễm sang những bệnh không lây nhiễm theo mô hình bệnh tật của một xã hội hiện đại. Tỷ lệ người cao tuổi tham gia hệ thống hưu trí và trợ cấp xã hội còn thấp và mức hưởng còn thấp và chiếm tỷ lệ nhỏ so với tổng thu nhập của hộ gia đình cao tuổi (UNFPA, 2011). Như vậy, việc nâng cao hệ thống chính sách, chương trình cho người cao tuổi là rất cần thiết. Các dịch vụ công tác xã hội cũng cần được hoàn thiện, mở rộng và nâng cao tính chuyên nghiệp trợ giúp người cao tuồi trong xu hướng hội nhập quốc tế mạnh mẽ. Cần tiếp tục học hỏi các mô hình công tác xã hội chuyên nghiệp từ các nước phát triển trong công tác xã hội với người cao tuổi. Việt Nam có thể tham chiếu các mô hình công tác xã hội với người cao tuổi sau đây ở Hoa Kỳ trên nền tảng kinh tế, xã hội và văn hóa của Việt Nam:

- Dịch vu săn sóc tại gia (In Home Supportive Services Program - IHSS): Dịch vụ này cung cấp sự trợ giúp cho người cao niên, khuyết thị, và tàn tật không thể sống an toàn tại nhà được nếu không có sự săn sóc của người khác. IHSS có một đội ngũ nhân viên đa ngành và đa văn hóa có thể thẩm định khả năng sinh hoạt của thân chủ và xác định số giờ cần thiết để thực hiện một số dịch vụ săn sóc tại gia. Các dịch vụ này bao gồm quét dọn nhà cửa, soạn bữa ăn, đi mua sắm và làm việc linh tinh cũng như săn sóc cá nhân không có tính cách y khoa như tắm rửa, thay quần áo và chải chuốt diện mạo. Thân chủ của IHSS có thể tự mướn người săn sóc mình hoặc tìm người qua hệ thống đăng ký.

- Dịch vu bảo vệ nguời lớn (Adult Protective Services - APS): Dịch vụ này đảm bảo sự an toàn cho người cao niên và người lớn không thể sống tự lực trong cộng đồng. Các cán sự xã hội và nhân viên hỗ trợ của APS cung cấp những dịch vụ xã hội toàn diện cho các nạn nhân bị ngược đãi và/hoặc bị bỏ bê. Nhân viên APS đáp ứng ngay lập tức khi được báo cáo có nguy hiểm hay đe dọa tức thì, 24 giờ mỗi ngày và 7 ngày mỗi tuần. Mục tiêu của APS 
là bảo vệ và ngăn chặn nguy cơ những người cao niên và người lớn không thể sống tự lực bị ngược đãi hay bị bỏ bê. Nhân viên APS quảng bá sự độc lập, gia tăng các ưu điểm cá nhân, thiết lập các hệ thống hỗ trợ và bênh vực quyền lợi của thân chủ nhằm giảm thiểu khả năng thân chủ bị ngược đãi hay bỏ bê.

\section{KẾT LUẬN}

Nước ta cơ bản còn là một nước nghèo, ngoại trừ một số nhỏ giàu có nhờ kinh tế thị trường, đời sống đa số dân chúng nói chung còn nhiều vất vả, khó kiếm được công ăn việc làm bền vững và tạo ra thu nhập ổn định. Chưa kể nhiều vấn đề xã hội phát triển nhanh chóng, tình trạng tham nhũng, bất công xã hội còn nhiều. Điều này ảnh hưởng đến khả năng chăm sóc cha mẹ già yếu trong các gia đình Việt Nam.

Trong lĩnh vực người cao tuổi, Việt Nam hiện đang đối mặt với ba vấn đề lớn liên quan đển quá trình già hóa dân số và sự gia tăng về số lượng cũng như tỉ trọng người cao tuổi, đó là: Số lượng người cao tuổi tăng nhanh; Nhiều người cao tuổi sống ở mức nghèo và cận nghèo; và Hầu hết người cao tuổi có sức khỏe kém, có xu hướng sống đơn thân bởi sự hỗ trợ từ gia đình và người thân đang dần thu hẹp lại (Nguyễn \& Phạm, 2015). Mặc dù có nhiều chính sách, luật, nghị định, chương trình của Nhà nước và các hoạt động chăm sóc cho người cao tuổi trong gia đình và cộng đồng được triển khai, tuy nhiên hoạt động chăm sóc cho người cao tuổi ở Việt Nam còn nhiều hạn chế và bất cập, công tác chăm sóc cho người cao tuổi chưa được quan tâm đúng mức. Ngoài các cơ sở chăm sóc có được như hiện nay, việc thành lập các trung tâm chăm sóc người cao tuổi (mô hình kết hợp nhà nước và tư nhân, xã hội. Trong đó nhà nước đóng vai trò quản lý) là cần thiết, đồng thời đào tạo nguồn nhân lực công tác xã hội trong chăm sóc người cao tuổi là một đòi hỏi thực tiễn mang tính tất yếu, khách quan. Việc học hỏi các mô hình công tác xã hội với người cao tuổi chuyên nghiệp của các quốc gia phát triển là điều rất cần thiết nhằm đáp ứng nhu cầu chăm sóc và an sinh xã hội tốt nhất cho người cao tuổi. Người cao tuổi khi đã cống hiến sức lực, trí tuệ, kỹ năng cho xây dựng và phát triển đất nước, thì họ có quyền được hưởng sự chăm sóc, hỗ trợ của nhà nước và xã hội (Lê, 2014).

Về măt lý luận, quan niệm mới về công tác xã hội nói chung và công tác xã hội với người cao tuổi nói riêng tập trung vào chât lượng cuộc sống, vào việc cải thiện mồi trường và hệ thống chính sách. Với lĩnh vực người cao tuổi, quan niệm này lạc quan và tích cực hơn quan niệm cũ về người cao tuổi có bệnh tật/không bệnh tật, bởi "sinh - lão - bệnh - tử" là tất yếu. Cũng theo quan niệm mới này, người cao tuổi không nơi nương tựa hoặc mắc bệnh nan y không thể chữa trị vẫn có thể có một cuộc sống chất lượng và ý nghĩa nếu được giúp đỡ một cách đúng đắn. Trong cách giúp đỡ đúng đắn có phần đóng góp của nhiều ngành như y khoa, vật lý trị liệu, tâm lý trị liệu, công tác xã hội, tôn giáo... Vai trò của công tác xã hội quan trọng ở chỗ nó giữ phần điều phối tất cả các phương tiện, các tài nguyên, để người cao tuổi đạt được cuộc sống với chất lượng cao nhất có thể. 


\section{TÀI LIỆU THAM KHẢO}

Bùi, T. T. H. (2015). Hạn chế và thách thức của công tác xã hội trong chăm sóc người cao tuổi hiện nay. Tạp chí Xã hội học, (4), 17-24.

Giang, L. T. (2013). Tổng quan các mô hình chăm sóc tại công đồng cho nguời cao tuổi Việt Nam. Bài báo trình bày tại Hội thảo Thích ứng với già hóa dân số nhanh: Trao đổi kinh nghiệm quốc tế về các chính sách và hành động, Việt Nam.

Lê, V. K. (2014). Vấn đề về người cao tuổi ở Việt Nam hiện nay. Tạp chí Khoa học Xã hội Việt Nam, (7), 77-87.

Nguyễn, H. L., \& Nguyễn, T. H. (2015). Giáo trình Công tác xã hội đại cuơng. Hà Nội, Việt Nam: NXB. Đại học Quốc gia Hà Nội.

Nguyễn, H. T., \& Phạm, L. D. (2015). Kinh nghiệm chăm sóc người cao tuổi tại Trung Quốc và Nhật Bản. Bài báo trình bày tại Hội thảo Khoa học Quốc tế Công tác Xã hội Việt Nam: Thách thức tính chuyên nghiệp trước nhu cầu hội nhập và phát triển, Việt Nam.

Nguyễn, N. H., \& Hines, A. (2011). Về luận văn thạc sĩ ngành công tác xã hội: Mô hình tù các truoòng đại học Mỹ. Bài báo trình bày tại Hội thảo Kỷ niệm 20 năm Khoa Xã hội học, Trường Đại học Khoa học Xã hội và Nhân văn, Đại học Quốc gia Hà Nội, Việt Nam.

Trần, Đ. T. (2017). Trao đổi cá nhân.

Trịnh, D. L. (2016). Chính sách chăm sóc người cao tuổi ở Việt Nam hiện nay. Tạp chí Khoa học Xã hội Việt Nam, (1), 26-30.

UNFPA. (2011). Già hóa dân số và người cao tuổi ở Việt Nam: Thực trạng, dụ báo và một số khuyến nghị chính sách. Hà Nội, Việt Nam: Quỹ Dân số Liên hợp quốc tại Việt Nam.

Văn phòng Chính phủ. (2012). Quyết định phê duyệt chương trình hành động quốc gia về nguời cao tuổi Việt Nam giai đoạn 2012 - 2020. Hà Nội, Việt Nam: Văn phòng Chính phủ.

VUSTA. (2007). Chỉ thị số 59-CT/TW, ngày 27/9/1995 của Ban chấp hành TW Đảng Cộng sản Việt Nam về chăm sóc người cao tuổi. Được truy lục từ http://www. vusta.vn/vi/news/dang-nha-nuoc-va-tc-khac/chi-thi-so-59-ct-tw-ngay-27-9-1995 -cua-ban-chap-hanh-tw-dang-cong-san-viet-nam-ve-cham-soc-nguoi-cao-tuoi-18 412.html. 